\title{
PENGALAMAN KLIEN DIABETES MELITUS TIPE 2 PASCA AMPUTASI MAYOR EKSTREMITAS BAWAH
}

\author{
Yeni Agustin ${ }^{1,2 *}$, Elly Nurachmah ${ }^{3}$, I Made Kariasa ${ }^{3}$ \\ 1. Rumah Sakit Pertamina, Balikpapan 76111, Indonesia \\ 2. Program Studi Magister, Fakultas Ilmu Keperawatan, Universitas Indonesia, Depok 16424, Indonesia \\ 3. Fakultas Ilmu Keperawatan, Universitas Indonesia, Depok 16424, Indonesia \\ *E-mail: yeniagustin.ns@gmail.com
}

\begin{abstract}
Abstrak
Diabetes Melitus Tipe 2 (DM Tipe 2) adalah kelainan metabolik yang ditandai dengan hiperglikemia yang diakibatkan kurangnya sekresi insulin, resistensi insulin, atau keduanya. Kondisi hiperglikemia kronis dapat menyebabkan berbagai komplikasi yang salah satunya adalah kaki diabetik yang menjadi penyebab utama dilakukannya amputasi pada klien DM tipe 2. Penelitian ini bertujuan untuk mengetahui pengalaman klien DM tipe 2 pasca amputasi mayor ekstremitas bawah. Penelitian ini menggunakan metode kualitatif dengan pendekatan fenomenologi. Hasil analisis data menghasilkan enam tema, yaitu: perubahan dalam kehidupan setelah amputasi, respon atau perasaan terkait amputasi, mekanisme koping, dukungan sosial yang diterima, makna hidup, dan pelayanan kesehatan yang diterima. Hasil penelitian ini diharapkan dapat menjadi masukan dalam meningkatkan kualitas asuhan keperawatan melalui peningkatan dukungan rehabilitasi secara fisik, psikososial, dan spiritual pada klien DM tipe 2 pasca amputasi mayor ekstremitas bawah.
\end{abstract}

Kata kunci: amputasi mayor ektremitas bawah, diabetes melitus tipe 2, fenomenologi, pengalaman klien

\section{Abstract}

Experiences of Type 2 Diabetes Clients Following Major Limbs Amputation. Type 2 Diabetes Mellitus (type 2 DM) is a metabolic disorder characterized by hyperglycemia as a result of insulin deficiency, insulin resistance, or both. Chronic hyperglycemia conditions can lead to complications such as a diabetic foot as a major cause of amputation among clients with type 2 DM. The purpose of this study was to determine the experiences of clients with type 2 DM following major lower limbs amputation. This study used a qualitative method with phenomenology approach. Six themes revealed: live changes of amputees, amputation response or related feelings, coping mechanisms, social support received, the meaning of life, and health care received. The results of this research are expected to contribute positively in improving the quality of nursing care through physical, psychosocial, and spiritual rehabilitation support provided to clients with type 2 DM following major lower limbs amputation.

Keywords: experience, major lower limb amputation, phenomenology, type 2 diabetes mellitus

\section{Pendahuluan}

Kaki diabetik merupakan penyebab umum dilakukannya tindakan amputasi pada klien dengan Diabetes Mellitus (DM). Diperkirakan 40\% hingga $70 \%$ amputasi ekstremitas bawah dialami oleh klien dengan DM yang bermula dengan ulkus kaki (Dunning, 2009). Kasus amputasi akibat komplikasi DM masih banyak ditemukan di Indonesia. Pada tahun 2007 di ruang perawatan penyakit dalam RSUP. Cipto Mangunkusumo Jakarta terdapat 111 klien diebetes yang dirawat dengan masalah kaki diabetik dan $35 \%$ di antaranya harus dilakukan tindakan amputasi yang terdiri dari $30 \%$ amputasi mayor dan $70 \%$ amputasi minor dengan jumlah angka kematian akibat amputasi tersebut sekitar $15 \%$. Selanjutnya data pada tahun 2010 hingga 2011 di rumah sakit yang sama memperlihatkan peningkatan jumlah amputasi menjadi $54 \%$ yang sebagian besar terdiri dari amputasi minor sebesar $64,7 \%$ dan amputasi mayor sebesar 35,3\% (Pusat Data dan Informasi Perhimpunan Rumah Sakit Indonesia [PDPERSI], 2011). 
Amputasi ekstremitas bawah dapat menyebabkan berbagai perubahan dalam kehidupan pada klien yang mengalaminya. Klien yang mengalami amputasi ektremitas bawah akan merasakan perubahan pada citra tubuh dan identitas diri, serta masalah ketika berhubungan dengan orang lain (Senra, Oliveira, Leal, \& Vieira, 2011). Amputasi mayor ekstremitas bawah tidak hanya memberikan dampak pada aspek fisik, tetapi juga memberikan dampak pada psikososial klien yang mengalaminya. Penelitian ini bertujuan untuk menggali lebih dalam mengenai pengalaman klien DM setelah mengalami amputasi mayor ekstremitas bawah dari aspek psikososial, spiritual, adaptasi, dan makna hidup, serta pelayanan kesehatan yang diterima pasca amputasi mayor ekstremitas bawah yang dialami.

\section{Metode}

Penelitian ini menggunakan metode penelitian kualitatif dengan pendekatan fenomenologi deskriptif. Penelitian ini dilakukan di Poliklinik RSUP. Cipto Mangunkusumo Jakarta sebagai tempat penentuan dan pengambilan partisipan, sedangkan pengambilan data melalui wawancara dilakukan di rumah partisipan pada September hingga Desember 2012. Pemilihan partisipan pada penelitian ini menggunakan teknik purposive sampling. Partisipan dipilih berdasarkan kriteria inklusi yang telah ditetapkan yaitu klien yang didiagnosis DM tipe 2, pernah menjalani amputasi mayor ekstremitas bawah dan belum menggunakan prostetik, status kognitif baik berdasarkan uji Short Portable Mental Status Questionnaire (SPMSQ), mampu berkomunikasi dengan baik menggunakan bahasa Indonesia, bersedia dilakukan wawancara mendalam untuk mengeksplorasi pengalamannya, serta mampu menceritakan dengan baik mengenai pengalamannya.

Teknik pengumpulan data yang digunakan dalam penelitian ini adalah wawancara mendalam dan catatan lapangan. Analisis data dalam penelitian ini menggunakan metode Collaizi. Adapun tiap hasil wawancara dengan para partisipan, dilakukan content analysis secara keseluruhan yang mengacu pada tujuan penelitian dan menghasilkan beberapa tema utama.

\section{Hasil}

Partisipan yang berpartisipasi dalam penelitian ini berjumlah 6 orang dengan rentang usia berkisar antara 49-62 tahun (rata-rata 55,3 tahun) dan lama terdiagnosa DM tipe 2 antara 7-19 tahun (rata-rata 11,7 tahun) dengan lama amputasi berkisar antara 6-36 bulan (rata-rata 26,2 bulan). Berdasarkan jenis kelamin, partisipan yang berjenis kelamin laki-laki berjumlah 5 orang dan perempuan berjumlah 1 orang. Berdasarkan suku, partisipan yang berasal dari suku Jawa berjumlah 3 orang, Betawi berjumlah 1 orang, Batak berjumlah 3 orang, dan partisipan yang berasal dari suku Sunda berjumlah 1 orang. Berdasarkan agama yang dianut, sebanyak 4 partisipan beragama Islam dan 2 partisipan beragama Kristen. Berdasarkan tingkat pendidikan, partisipan yang berpendidikan Diploma berjumlah 1 orang, SMU berjumlah 1 orang, SMP berjumlah 2 orang, dan partisipan yang berpendidikan SD berjumlah 2 orang. Berdasarkan pekerjaan, sebanyak 2 partisipan merupakan pensiunan perusahaan swasta, 1 partisipan bekerja sebagai pengajar, 2 partisipan bekerja sebagai pedagang, dan 1 partisipan bekerja sebagai supir. Berdasarkan jenis amputasi yang dialami, sebanyak 4 partisipan mengalami amputasi di atas lutut (above-knee) dan 2 partisipan mengalami amputasi di bawah lutut (below-knee). Berdasarkan analisis data secara induktif menggunakan metode Collaizi, ditemukan 6 tema yang menjelaskan tentang pengalaman klien DM tipe 2 pasca amputasi mayor ekstremitas bawah, yaitu perubahan dalam kehidupan setelah amputasi, respon atau perasaan terkait amputasi, mekanisme koping, dukungan sosial yang diterima, makna hidup, dan pelayanan kesehatan yang diterima.

\section{Perubahan dalam Kehidupan setelah} Mengalami Amputasi. Pada tema ini, partisipan menyatakan bahwa ada perubahan-perubahan yang dirasakan setelah mengalami amputasi mayor ekstremitas bawah seperti adanya perubahan fisik, konsep diri, dan hubungan sosial. 
Perubahan fisik yang dirasakan oleh partisipan setelah mengalami amputasi mayor ekstremitas bawah adalah gangguan mobilitas, kehilangan kemandirian, dan perubahan fungsi seksual.

“...kadang-kadang kan susah juga lah apapun ya tergantung sama suami...saya kan apa-apa itu kan repotnya nggak bisa mandiri, harus suami...selalu ngerepotin... harus nanti dibopong-bopong suami..." (P4).

“...yang biasa semula bisa bergaul (aktivitas seksual), sekarang nggak bisa bergaul gitu...saya nggak tahu, setelah diamputasi itu...saya rasa, satu dari gula yah, keduanya, mungkin setelah amputasi juga ada lebih...lebihnya lagi..." (P2).

Hampir semua partisipan mengungkapkan pernyataan yang menggambarkan tentang adanya perubahan konsep diri yang dialami setelah amputasi mayor ekstremitas bawah seperti perubahan peran, citra tubuh, dan harga diri rendah.

“...kita gak seperti orang yang sempurna... saya ini laen sendiri kan dengan orangorang ini masyarakat, saya saya laen sendiri, pake tongkat jalannya gitu..." (P2).

Beberapa partisipan mengungkapkan pernyataan yang menggambarkan adanya perubahan dalam hubungan sosial seperti berkurangnya intensitas untuk bertemu kerabat atau ikut serta dalam kegiatan sosial.

“...perbedaannya nggak bisa terlalu ini lah sama temen jarang ketemu...perbedaannya biasa bisa kumpul ngaji, enggak...biasa bisa kondangan enggak....biasanya kalo kondangannya sama suami nih suami kondangannnya sendiri..." (P4).

Respon atau Perasaan setelah Mengalami Amputasi. Respon atau perasaan yang diungkapkan oleh partisipan meliputi respon fisik dan psikologis. Respon fisik yang dirasakan oleh mayoritas partisipan adalah munculnya nyeri pasca operasi dan nyeri pantom serta gangguan tidur. “...kayaknya kaki masih ada, kaya baru pulang gitu, baru pulang dari rumah sakit, mang seperti kaya masih ada tuh...rasa sakitnya tuh kaya di ujung kaki...waktu menjelang malem itu saya nggak bisa tidur...mikirin nanti di masyarakat saya gimana nih, bisa ini nggak, bergaul di masyarakat, aktivitas saya bisa kembali apa enggak, jadi dipikir nggak bisa tidur..."(P2).

Adapun respon psikologis setelah mengalami amputasi yang diungkapkan oleh partisipan adalah marah, stres, cemas, menangis, menyesal, dan menerima.

“...agak stres tadinya, ya... bagaimana tuh bergaul di masyarakat, kemudian aktivitasnya bisa apa namanya seperti semula apa enggak gitu...sempet stres juga memang, kita ini sebab kita ini jalannya juga susah jalan sendiri, pakai tongkat kan...”(P2).

Mekanisme Koping. Berbagai mekanisme koping digunakan oleh masing-masing partisipan dalam mengatasi permasalahan sebagai dampak amputasi seperti meningkatkan integritas spiritual, berusaha melakukan aktivitas secara mandiri, mencari dukungan, dan introspeksi diri.

"...lebih mendekat sekarang ya, karena ya...kita sekarang udah banyak di rumah, gak seperti dulu... ya banyak ibadah kepada Allah...seperti shalat, dan lainnya, berdo'a, dzikir." (P2).

“...saya pelan-pelan saya nyolong-nyolong ke dapur kalo malem belajar gitu saya angkat piring...lama-lama saya belajar nyuci piring...jadi bertahap, kalo baru-baru tuh kondisinya bener-bener lemah, terus sedikit demi sedikit saya trus ini bisa nyuci piring, lama-lama sehat, mandi, nyuci pakaian sekarang dagang saya..." (P4).

Dukungan Sosial yang Diterima. Berdasarkan hasil wawancara, mayoritas partisipan menyatakan bahwa semenjak amputasi dirinya mendapatkan dukungan sosial yang berasal dari keluarga, masyarakat, dan perawat. 
“...sempet stres juga memang kita ini sebab kita ini jalannya juga susah jalan sendiri, pakai tongkat kan, tapi setelah saya pikirpikir dan juga dorongan dari masyarakat yang juga mereka itu mengharapkan saya juga seperti biasa mengajar-mengajar gitu, jadi saat itu besar hati kita itu...” (P2).

Makna Hidup. Hampir semua partisipan menemukan makna hidup setelah mengalami amputasi seperti menganggap bahwa amputasi dapat meringankan beban. Selain itu, partisipan juga memaknai hidupnya bahwa meskipun dengan kekurangan masih dapat bermanfaat bagi orang lain.

“...adapun aktivitas kalo memang gak bisa saya laksanakan artinya mengurangi beban saya, tugas saya gitu...yah...selalu berpikir positif saya..." (P2).

“...walaupun saya cacat yang penting masih ada gunanya gitu lah...walaupun cacat masih bisa masakin suami, masih bisa ngerawat anak-anak, masakin anakanak, masih bisa nyuciin pakaiannya, masih bisa membelanjain sayuran..." (P4).

Pelayanan Kesehatan yang Diterima. Berdasarkan hasil wawancara, diperoleh informasi mengenai pengalaman terkait pelayanan kesehatan yang diterima pasca amputasi mayor ekstremitas bawah, baik selama dirawat di rumah sakit maupun setelah pulang dari rumah sakit. Adapun pengalaman-pengalaman yang diungkapkan tersebut meliputi kualitas pelayanan yang baik, sikap petugas kesehatan, bentuk pelayanan yang diterima, dan hambatan ketika melakukan pengobatan.

“...menurut saya bagus lah, setiap jadwal pemeriksaan tuh tepat waktu...nggak disiasiakan ya, cepat, waktunya periksa, periksa.. saya banyak terima kasih... sehingga saya bisa bermasyarakat lagi, badan saya sembuh, kan begitu, gitu aja...” (P2).

Beberapa partisipan mengungkapkan pengalamannya terkait bentuk pelayanan yang diterima seperti perawatan di rumah, latihan mobilisasi, perawatan luka, dan pemberian edukasi yang diberikan oleh tenaga kesehatan.

"Menurut saya baik Mbak, saya pas habis operasi malah ada (dokter) yang datang kesini kan Mbak...paling disarankan untuk latihan menggerak-gerakkan aja Mbak waktu itu, diangkat, ngangkat gini, ngangkat kaki, gitu...(sambil mengangkat kaki)" (P1).

Satu partisipan mengungkapkan tentang hambatan ketika melakukan pengobatan, yaitu menunggu dalam waktu yang lama untuk mengantri dan kesulitan dalam hal menyelesaikan administrasi.

“...bagus pelayanannya, ya memang segala sesuatu yang namanya berobat jangankan yang gratis, umum juga, ya masalah ngantri ya tetep ngantri, ya kan, apalagi kita yang namanye gratis, ngantri ya itu udah pasti harus sabar...emang terus terang nih kadang memang kadang agak kesel juga, yaitu di UPPJnya itu, di UPPJnya itu, memang agak, kadang suka agak sulit juga..." (P6)

\section{Pembahasan}

Berbagai perubahan dalam kehidupan dialami oleh partisipan setelah amputasi. Horgan dan MacLachlan (2004) menyebutkan bahwa individu dengan amputasi dihadapkan dengan adaptasi terhadap beberapa kehilangan dan perubahan-perubahan di dalam gaya hidup, interaksi sosial, dan identitasnya. Salah satu perubahan terbesar yang menyebabkan individu harus menyesuaikan diri setelah amputasi adalah hilangnya fungsi fisik dan kemandirian. Pada tahap pasca amputasi awal, individu dengan amputasi ekstremitas bawah dihadapkan dengan kesulitan dalam hal mobilitas.

Adanya gangguan mobilitas akibat dari amputasi tampaknya menjadi penyebab utama terjadinya restriksi sosial yang dialami partisipan. Disabilitas atau ketidakmampuan sering menyebabkan perubahan dalam hubungan atau interaksi sosial karena mereka harus membatasi sejumlah aktivitas sosial sehingga mengakibatkan adanya isolasi sosial. Bahkan ketika individu dengan 
disabilitas atau ketidakmampuan ingin mencoba untuk tetap aktif secara sosial, mereka akan mengalami kesulitan untuk bergabung di dalam masyarakat karena hambatan lingkungan (Falvo, 2005).

Selain gangguan mobilitas dan kemandirian, perubahan fungsi seksual juga dialami partisipan setelah amputasi. Wallis (2000) menyebutkan bahwa perubahan fungsi seksual sering dialami oleh klien pasca amputasi. Kondisi ini dipengaruhi oleh banyak faktor seperti penyakit vaskular perifer yang menyebabkan disfungsi ereksi, anemia sebagai efek dari pembedahan, dan kelelahan. Obat-obatan seperti analgesik, antiemetik, dan hipertensi juga dapat mengganggu fungsi seksual. Selain itu, harga diri rendah, perubahan citra tubuh, perasaan tidak menarik, dan depresi dapat pula menyebabkan dampak pada fungsi seksual klien pasca amputasi.

Amputasi menyebabkan nyeri dan hal tersebut dirasakan oleh sebagian besar klien pasca amputasi. Salah satu jenis nyeri yang dirasakan adalah nyeri pantom. Nyeri dapat dirasakan seperti kesemutan, pegal, atau berdenyut (Ehde et al., 2000). Nyeri pantom dialami oleh sekitar $85 \%$ klien pasca amputasi dan umumnya menetap tergantung pada pengobatan yang dilakukan (Madabhushi, Reuben, Steinberg, \& Adesioye, 2007).

Reaksi cemas, menangis, dan menyesal dialami oleh partisipan ketika mereka telah menyadari adanya perubahan pada fisiknya. Depresi muncul ketika seseorang menyadari tentang adanya kehilangan dan dampaknya. Pada tahap ini reaksi-reaksi emosi muncul seperti menangis, menarik diri, kehilangan nafsu makan, dan gangguan tidur (WHO, 2004). Williamson, Schultz, Bridges, dan Behan (1994) dalam Briggs (2006) menyebutkan bahwa kesehatan mental seseorang setelah amputasi dapat dipengaruhi secara langsung oleh berbagai faktor seperti masalahmasalah yang mencakup aspek sosial, psikologis, keuangan, dan kesehatan.
Salah satu mekanisme koping yang digunakan oleh partisipan dalam mengatasi berbagai permasalahan sebagai dampak amputasi adalah meningkatkan integritas spiritual. O’Brian (1998) dalam Salehi, Ghoudousi, dan Khadijeh (2012) menyatakan bahwa amputasi yang diakibatkan karena diabetes dapat menimbulkan krisis pada kehidupan fisik, mental, dan spiritualnya. Hal ini menghadapkan mereka pada kondisi stres berat yang pada akhirnya menuntun mereka dalam mencari pendekatan-pendekatan yang berbeda untuk mengatasi dan beradaptasi dalam kehidupan. Koenig (2004) dalam Salehi, Ghoudousi, dan Khadijeh (2012) menyatakan bahwa agama dapat menciptakan perilaku yang positif dalam menghadapi dunia dan menguatkan seseorang ketika menghadapi peristiwa atau musibah dalam kehidupan melalui motivasi dan energi. Perilaku ini dapat meningkatkan toleransi dan penerimaan akan situasi yang tidak dapat diubah.

Selain pendekatan spiritual, adanya semangat dan dukungan sosial juga tampak sebagai faktor yang meningkatkan penerimaan partisipan terhadap amputasi. Dukungan sosial sangat berkontribusi terhadap penerimaan dan penyesuaian setelah amputasi. Dalam hal ini, faktor kognitif juga berperan penting dimana seseorang yang memiliki harapan dan motivasi yang tinggi akan menghasilkan perilaku adaptif seperti mencari dukungan sosial dan berusaha untuk menyesuaikan atau beradaptasi yang pada gilirannya akan menyebabkan perasaan dan penyesuaian yang positif (Unwin, Kacperek, \& Clark, 2009).

Berbagai permasalahan yang diakibatkan oleh perubahan pasca amputasi memberikan makna hidup bagi partisipan. Beberapa makna hidup yang disampaikan oleh partisipan mengandung makna yang positif dan berdasarkan makna hidup yang disampaikan tampak bahwa partisipan sudah dapat menerima serta menyesuaikan terhadap dampak dan perubahan yang diakibatkan oleh amputasi. Menemukan makna yang positif secara signifikan berkaitan dengan kemampuan fisik dan tingkat kesehatan yang lebih baik, 
tingkat restriksi aktivitas yang lebih rendah, dan tingkat penyesuaian yang lebih tinggi terhadap keterbatasan fisik setelah amputasi (Gallagher \& MacLachlan, 2000).

Pemulihan klien yang mengalami amputasi sangat dipengaruhi oleh gambaran pelayanan kesehatan yang diterima terutama pada proses rehabilitasi pasca amputasi. Klien yang menerima program rehabilitasi khusus cenderung mendapatkan manfaat lebih besar dibandingkan klien yang hanya menerima konsultasi dan hal ini dapat dinilai dari kemampuan fungsional klien pasca amputasi (Stineman et al., 2010). Tim rehabilitasi yang berkoordinasi dengan staf perawatan akut dapat membantu penatalaksanaan klien pasca amputasi. Intervensi rehabilitasi yang tepat dapat membantu individu pasca amputasi memaksimalkan kemampuan fisik dan fungsional serta penyesuaian secara psikologis terhadap kehilangan yang diakibatkan karena amputasi (Kuiken, Huang, dan Harden, 2002).

\section{Kesimpulan}

Amputasi mayor ekstremitas bawah dapat berdampak signifikan pada kehidupan klien. Dampak tersebut terlihat dari perubahan-perubahan yang terjadi dalam kehidupan klien baik perubahan secara fisik maupun psikososial. Aspek spiritual, dukungan sosial, dan pelayanan kesehatan yang diterima merupakan faktor penting yang dapat membantu dan mempengaruhi penerimaan serta penyesuaian terhadap perubahan-perubahan yang dialami oleh klien DM tipe 2 pasca amputasi mayor ekstremitas bawah (US, ENR, TN).

\section{Referensi}

Briggs, W. (2006). The mental health problems and needs of older people following lower limb amputation. Clinical Gerontology, 16, 155-163.

Dunning, T. (2009). Care of people with diabetes: A manual of nursing practice. Singapore: Willey-Blackwell.

Ehde, D.M., Czerniecki, J.M., Smith, D.G., Campbell, K.M., Edwards, T.,Jensen, M.P., et al. (2000). Chronic phantom sensations, phantom pain, residual limb pain, and other regional pain after lower limb amputation. Archive Physical Medicine Rehabilitation, 81, 1039-044.

Gallagher, P., \& MacLachlan, M. (2000). Positive meaning in amputation and thoughts about the amputated limb. Prosthetics and Orthotics International, 24 (3), 196-204.

Falvo, D. (2005). Medical and psychosocial aspect of chronic illness and dissability. Sudbury, MA: Jones and Bartlett Publishers.

Horgan, O., \& MacLachlan, M. (2004). Psychosocial adjustment to lower-limb amputation: A review. Disability and Rehabilitation, 26 (14), 837-850.

Kuiken, T., Huang, M., \& Harden, N. (2002). Perioperative rehabilitation of the transtibial and transfemoral amputee. Physical Medicine and Rehabilitation, 16 (3), 521-537.

Madabhushi, L., Reuben, S.S., Steinberg, R.B., \& Adesioye, J. (2007). The efficacy of postoperative perineural infusion of bupivacaine and clonidine after lower extremity amputation in preventing phantom limb and stump pain. Journal of Clinical Anasthesia, 19 (3), 226-229.

Pusat Data dan Informasi Perhimpunan Rumah Sakit Indonesia. (2011). RI rangking keempat jumlah penderita diabetes terbanyak dunia. Diperoleh dari http://www.pdpersi.co.id/con tent $/$ news.php? mid $=5 \&$ nid $=618 \&$ catid $=23$.

Salehi, S., Ghodousi, A., \& Ojaghloo, K. (2012). The spiritual experiences of patients with diabetes-related limb amputation. Iranian Journal of Nursing and Midwifery Research, 17 (3), 225-228.

Senra, H., Oliveira, R.A., Leal, I., \& Vieira, C. (2011). Beyond the body image: A qualitative study on how adults experience lower limb amputation. Clinical Rehabilitation, 26 (2), 180-191.

Stineman, M.G., Kwong, P.L., Xie, D., Kurichi, J.E., Ripley, D.C., Brooks, D.M., et al. 
(2010). Prognostic differences for functional recovery after major lower limb amputation: Effects of the timing and type of inpatient rehabilitation services in the veterans health administration. American Academy of Physical Medicine and Rehabilitation, 2 (4), 232-243.

Unwin, J., Kacperek, Lynn., \& Clark, C. (2009). A prospective individu of positive adjustment to lower limb amputation. Clinical Rehabilitation, 23, 1044-1050.
Wallis, S. (2000). The Amputee. Dalam P. S. Davis (Editor), Nursing the Orthopaedic Patient (hal. 351-373). London: Churchill Livingstone.

World Health Organization. (2004). The rehabilitation of people with amputation. Diperoleh dari http://www.posna.org/news/ amputations.pdf. 